\section{Wetland Restoration in Japan: What's Law Got to Do with It?}

\author{
EVAN HAMMAN \\ Queensland University of Technology
}

\section{ABSTRACT}

Decades of destruction, land reclamation and pollution have wreaked havoc upon Japan's wetland environments. The government has responded by implementing new laws and policies that seek to reverse the declines by encouraging the involvement of the local community and NGO sector. At the same time, the government has also engaged with international and regional frameworks such as the Ramsar Convention and the East Asian-Australasian Flyway Partnership. This paper explores the interrelationship between Japanese law, international law and a 'restoration ethos' in Japan. It argues that the Japanese government's desire to restore the natural environment is ably supported by a legislative and policy framework which draws upon best practice in collaborative governance. By focusing on wetland restoration, the paper sheds light on the connections between local, national and international stakeholders. Wetlands provide important habitat for biodiversity (especially birdlife) as well as filtration and sediment control, and act as a natural buffer against disasters. Japan appears well-placed to reverse the declines in wetland health, although more needs to be done to reconnect with traditional socioecological landscapes such as satoumi and satoyama.

\section{KEYWORDS}

Act for the Promotion of Nature Restoration; birdlife; birds; collaborative governance; conservation; East Asia; ecological restoration; endangered species; international law; law; Ramsar Convention; wetlands

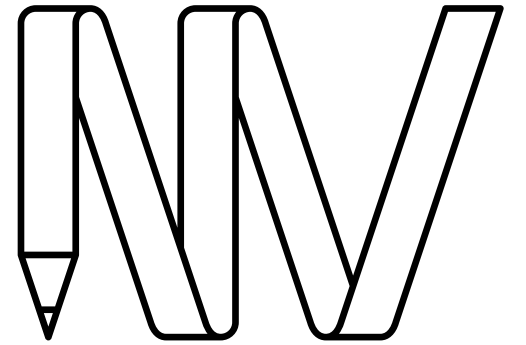

NEW

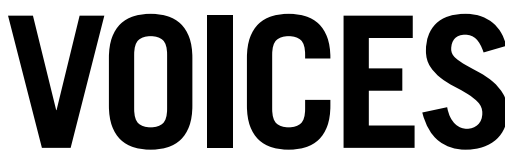

IN JAPANESE STUDIES

JAPANFOUNDATION \&

BRINGING JAPAN TO YOU

To link to this article:

https://doi.org/10.21159/nvjs.11.03

\section{ISSN 2205-3166}

New Voices in Japanese Studies is an interdisciplinary, peer-reviewed journal showcasing the work of emerging scholars with ties to Australia or New Zealand and research interests in Japan.

All articles can be downloaded free at newvoices.org.au

(c) The Japan Foundation, Sydney and Evan Hamman, 2019

\section{(c) $(1)$}

This work is licensed under a Creative Commons Attribution-NonCommercialNoDerivatives 4.0 International License. 
As in many parts of the world, Japan's wetlands are in decline (Davidson 2014). Land reclamations, agricultural drainage and pollution have dangerously disrupted the aquatic ecosystems on which Japan depends (Nakamura et al. 2006). Reclamation of tidal wetlands in Tokyo Bay and the Ariake Sea has been particularly debilitating for migratory shorebirds which rely on the mudflats for food in their long journeys from their breeding grounds in the north of Asia to their wintering grounds in the southern hemisphere (Ichikawa et al. 2017). The driver of much of this has been the relentless economic growth that Japan has pursued since the end of World War II. In the 1970s and 1980s, the mantra of "develop now, clean up later" was very much at the forefront of government thinking (Nakamura et al. 2006, 420). Roads, bridges, airports, industrial sites and even theme parks were all constructed with little or no concern for the environmental impacts and with few, if any, legal protections in place.

Since the 1990s, however, Japan has made a noticeable shift towards the 'restoration' of its wetlands. One of the turning points was a major wetlands conference held in 1993 in Kushiro, Hokkaido. The Kushiro Conference of the Parties (hereafter, 'the Kushiro COP') helped solidify Japan's place as one of the key players under the Ramsar Convention (hereafter, 'Ramsar'), the main international treaty that governs wetland conservation. ${ }^{1}$ At the Kushiro COP, Japanese non-government organisations (NGOs), ornithologists and bird enthusiasts were all integral in bringing the state of Japan's wetlands to the attention of the international community. Since then, environmental groups like Wetlands International (国際湿地の日本支部), Ramsar Network Japan (ラムサール・ネットワーク・ジャパン), Birdlife International (バードライフ・インタ 一ナショナル 東京) and the Wild Bird Society of Japan (日本野鳥学会) have advocated for more explicit and effective strategies on wetland conservation in Japan. With Ramsar Network Japan at the forefront, NGOs in Japan are pushing the Japanese government to designate a total of 100 Ramsar sites by 2030 (Ramsar Network Japan 2015). The MOEJ has officially adopted a more modest goal of 10 new sites to be designated between 2012 and 2020 (MOEJ 2012,142 ), but while only 8 new sites have been designated since 2012, other actions suggest that it may be open to further increasing designations in the future. $^{2}$ As at 2019, Japan has 52 Ramsar sites, with Kushiro wetlands the first site listed in 1980 (for a map of Ramsar sites in Japan, see Figure 1).

\footnotetext{
1 The Ramsar Convention on wetlands of international significance is the most important convention on wetland environments. It has been widely ratified, including by Japan. The Convention is often referred to as the Ramsar Convention, named after the Iranian city of its signing in 1971. Every three years, the nations that have signed the Convention meet to resolve the listing of wetland sites of international importance and discuss mechanisms for conservation and restoration. These meetings are known as 'Conferences of the [Ramsar] Contracting Parties' or 'COPs'. The main participants at COPs are delegates from the signatory nations, although there are many NGOs that also attend and host side events, share knowledge and run capacity-building sessions. The resolutions decided upon after each COP can be found on the Ramsar Convention Secretariat's website: https://www. ramsar.org/about/the-conference-of-the-contracting-parties. The designation process for listing wetlands of international importance in Japan (i.e., Ramsar sites) is outlined later in the paper. Definitions of specialist terms such as those outlined here are collated in a glossary at the end of this paper. A bilingual list of Japanese and international environmental governance frameworks cited in this paper is provided in Appendix 1.

2 As Ramsar Network Japan (2015) notes, "although the position of the [MOEJ] in 2005 was that about 50 Ramsar sites might be the upper limit, they announced as many as 172 candidate sites in September 2010. 


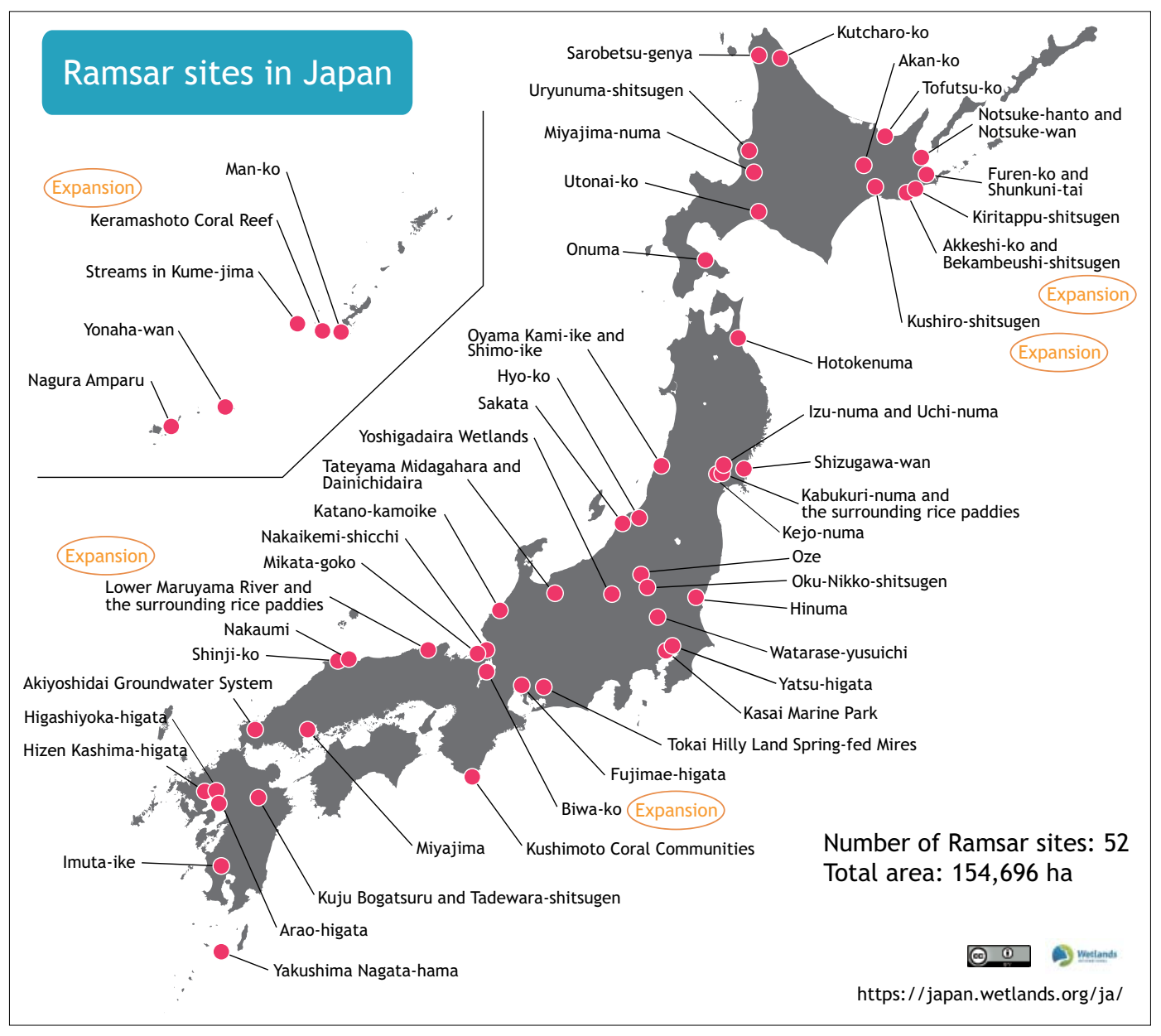

Figure 1: Ramsar Sites in Japan (as at May 2019)

Source: Wetlands International Japan (CC-BY).

This paper examines the role that law and culture have played, and should play, in the conservation and restoration of Japan's wetland environments. It argues that Japan's efforts to establish the institutional and legislative architecture necessary to drive wetland governance are supported by a 'restoration ethos' that can also be found in other examples of Japanese law. There are few examples around the world of law and culture intersecting in this way, and there is perhaps much that can be learned from the Japanese example. In addition to highlighting the relationships between Japan's environmental law and other domestic legislative instruments, the paper also shows-with a focus on wetland environments-how Japan's nature restoration frameworks simultaneously scaffold collaboration at both local and international levels. This is achieved through intersections with domestic legislation and international environmental governance frameworks on one hand, and through activation of the local government and NGO sectors on the other.

The paper is structured in three parts. Part one provides background to Japan's wetland environments, noting their significance as habitat for biodiversity as well as for agriculture, and highlighting the decline of Japan's wetlands largely due to coastal reclamation and rice paddy conversion. 
Part two introduces the concept of 'ecological restoration', drawing a link to a broader philosophy of 'recovery' or 'healing' in Japan referred to in this paper as a 'restoration ethos'. Part two also analyses the 2002 Act for the Promotion of Nature Restoration (自然再生推進法; hereafter, 'Nature Restoration Act'), and notes that Japan stands out as one of only a handful of nations to have passed legislation that aligns with the ecological restoration concept. Close to a dozen projects have been initiated under this law in Japan to date, and this part of the paper provides examples of those that relate to wetland environments. Finally, part three of the paper charts a path towards improved restoration efforts in Japan. It argues for a deeper connection with 'socio-ecological production landscapes' and highlights the importance of well-planned community engagement.

\section{WETLANDS IN JAPAN}

\section{What is a Wetland?}

The term 'wetland' ('湿地' in Japanese) is challenging to define. There is currently no formal definition under Japanese law as, unlike other Asian nations like South Korea and Taiwan, Japan lacks targeted national wetland legislation. A basic definition is likely to cover any land environment which at one time or another is submerged or partially submerged under water. Obvious inclusions in this definition are lakes, mangroves, peatlands and marshes. In a study of Hokkaido's wetlands, Fujita et al. (2009) defined wetlands as areas greater than one hectare "with natural vegetation under wet conditions such as mire (peatland), river flood plain, lakeshore, and seashore" (12). Japan's national biodiversity policy describes wetlands as a type of "inland water ecosystem" (MOEJ 2012, 45) although it stops short of ascribing a more detailed descriptive label to them.

Under Article 1.1 of the Ramsar Convention, wetlands are defined as:

areas of marsh, fen, peatland or water, whether natural or artificial, permanent or temporary, with water that is static or flowing, fresh, brackish or salt, including areas of marine water the depth of which at low tide does not exceed six metres.

Notably, Ramsar's definition (which is adopted in this paper) includes both natural and artificial sites. Accordingly, Japan's rice paddies might be classified as wetlands under international law. Indeed, rice paddies have become a vital component of the natural environment in Japan as habitat for waterbirds. There is considerable scientific evidence that bird species such as the Oriental Stork (Ciconia boyciana; コウノリリ) and Japanese Crested Ibis (Nipponia Nippon; トキ) thrive in rice-farming landscapes (Takahashi 2009, 1960). ${ }^{3}$ In fact, as Fujioka et al. (2010) have found, almost a third of Japan's bird species can be found in its rice paddy environments at some point in their life cycle. ${ }^{4}$ 
The manner in which wetlands are conceived has important ramifications for their effective conservation and wise use. Wetlands can and should be distinguished, for example, from other water-based environments such as river systems and the marine environment. Narrowing in on exactly what wetlands are allows for a more sophisticated understanding of their conservation needs, their hydrological inputs and outflows, and, ultimately, what an effective legislative and institutional policy response to their declines might look like.

\section{Distribution and Ecology}

Japan is a country of extraordinarily high rainfall (MOEJ n.d.[a]), particularly during the summer months, owing largely to the influence of the Asia monsoon (Mo et al. 2005, 82). It is also a nation which relies heavily on its rivers, wetlands and other aquatic environments for domestic consumption, commercial usage and rice cultivation (Haidary et al. 2013). Japan's rivers (of which there over 14,000) are classified as either 'class A', 'class B', 'secondary' or 'regular' depending upon their size and importance to the national government (Nakamura et al. 2006, 421). Japan has 109 'class A Rivers'-that is, rivers seen to be of crucial national importance, and which are owned and managed by the national government (Nakamura et al. 2006).

Japan's river systems support a wide variety of flora and fauna. Whilst Japan would not be classified as 'mega[bio]diverse' in the same way as Indonesia, the Philippines, Australia or China would (Mittermeier et al. 1997), it is still home to over " 160 species of mammals, 700 species of birds, 30,000 species of insects and 7,000 species of vascular plants" (MOEJ n.d.[a]). Japan's wetlands and woodlands in particular support the majority of its bird species. However, many of Japan's birds are migratory, and hence their survival relies heavily on what is happening elsewhere in the region, especially in China, Russia, Indonesia, South Korea, North Korea, Australia and the Philippines. All of these nations (and several others) have signed a regional agreement known as the East Asian-Australasian Flyway (EAAF) Partnership which seeks to conserve migratory waterbirds through management of the wetland areas they rely on. ${ }^{5}$ As a founding member, Japan currently has 33 'flyway sites'the most out of any nation in the Partnership.

In terms of variety of wetlands, Japan is home to marshes, tidal flats, coral reefs, mangroves, seaweed beds, rice paddies and reservoirs. Its tidal mudflats, known as higata (干潟) in Japanese, are areas of particularly rich and unique biodiversity. Japan's higata provide habitat for a variety of mud-dwelling organisms such as crabs, worms and sponges, which in turn attract the presence of hundreds of thousands of migratory waterbirds annually. Most of Japan's important higata are found in estuarine environments-that is, at 
the mouths of rivers-such as where the Tama River flows into Tokyo Bay, the Fushino River into Yamaguchi Bay, or where the Shiota and Kashima Rivers meet in the Ariake Sea. Japan's Ariake Sea in particular is biologically rich; this has been attributed to its temperate climate, considerable tidal variation and the presence of shoals which help to facilitate sediment deposition (Ramsar Sites Information Service 2015, 2).

\section{Declines and Threats}

While the story of Japan's post-war economic growth is well-documented, the impacts on its wetland environment are perhaps less well-publicised. The reclamation and drainage of Japan's wetlands, primarily for rice farming but also for port and urban development, is not a new phenomenon. In fact, Japan has a long history of degrading its wetlands (Dempster 1967, 150; Koh and De Jonge 2014). As Eyre (1956) points out, evidence of paddy reclamation in Kojima Bay (Okayama prefecture) can be traced back to the 1570s. Moreover, much of the city of Tokyo (previously, Edo) was constructed directly upon or adjacent to wetland environments (Ichikawa 1994; Hong and Iisaka 1982). Whilst early impacts of cities on wetlands were gradual given the limited nature of machinery, the "introduction of the bulldozer" in 1950 hastened the destruction of many wetland environments (McCormack 1996, 95). Satellite imagery, for instance, has shown the increased loss of tidal areas in Tokyo Bay during the 1970s and 1980s (Hong and Iisaka 1982; Endoh 2004), and this loss continues today, including in built up areas such as Haneda airport (Watabe and Sassa 2016).

The statistics paint a distressing scene. Up to $40 \%$ of Japan's higata are estimated to have been destroyed in the fifty years since the end of World War II (Shimba 2007, 11; MOEJ 2012, 46). On the island of Hokkaido, up to 70\% of original marshlands have been lost to agriculture (Fujita et al. 2009, 10). Further, reclamations along Japan's coastline have also been considerable. MOEJ estimates that about one-third of Japan's entire $32,800 \mathrm{~km}$ coastline could now be classified as 'artificial' (MOEJ n.d.[b]). However, reclamations and rice paddy conversions are not the only concern. Water pollution from nutrient loading and pesticides on farms has also had severe impacts, and so too has 'point source' pollution from industrial and chemical factories. Totman (2014) observes, for example, that much of the wetland degradation has been "accomplished through liquid waste" (510) from industrial sources. Nakamura et al. (2006) concur, writing: "the economic boom between 1950 and 1970 caused severe water pollution throughout the country" (420). These problems have either removed entirely or negatively affected the ecological character of many of Japan's wetland sites, hampering their capacity to act as buffer and filtration systems within the broader natural landscape.

Suffice it to say, the flow-on effect to Japan's biodiversity has been enormous. The declines are most clearly evidenced by the drop of migratory bird populations in Japan (Amano et al. 2010). Populations of waterbird species like the Dunlin (Calidris alpina; ハマシギ) have declined rapidly in recent years 
(Zöckler et al. 2003). As Ichikawa et al. (2017) report, in the past forty years, shorebird populations have "decreased drastically" across the nation (344). Asia's shorebirds are a group of waterbirds that breed in Alaska and Siberia and spend the winter in places like Japan, China, Australia and Korea. Numbers of the Eastern Curlew (Numenius madagascariensis; 木 ウロクシギ)—a passage migrant in Japan, and the largest shorebird in the world-have declined by up to $80 \%$ in three generations (EAAF Partnership n.d.). ${ }^{6}$ The Eastern Curlew is now listed by the International Union for the Conservation of Nature as "endangered", the second-highest threat category available before extinction (Birdlife International 2017).

Of course, the problems of declining waterbirds and wetland degradation are not unique to Japan. Other nations in Asia (South Korea and China in particular) have rapidly lost their wetlands due to agriculture and port development (Murray et al. 2014). China's Yellow Sea coast, including the Bohai Gulf, has become the new frontier in the fight to save Asia's waterbirds (Murray et al. 2014; Hamman 2018). The coastal mudflats of the Yellow Sea are the main staging and refuelling site for many hundreds of thousands of migratory waterbird species along the EAAF (Murray et al. 2014). However, rapid industrial development over recent decades has seen marked degradation and decline of its intertidal flats, which is heavily impacting upon the future survival of Asia's migratory birds. Accordingly, the outlook is presently dim for waterbird species across the region. Against this background, the next section of the paper discusses the relevance of international and domestic law in conserving and restoring Japan's wetland environments.

\section{Japan and the Ramsar Convention}

The Ramsar Convention is an international treaty which provides for the identification and conservation of wetlands of 'international significance'. Along with the Convention on Migratory Species, the Convention on Biological Diversity and the World Heritage Convention, Ramsar is one of the most important international environmental agreements. Ramsar currently has 170 member countries and a total of 2,326 Ramsar sites covering 250 million hectares. Although Japan joined Ramsar in 1980, it was not until the 1990s that it emerged as a major player in wetland conservation. Since then, the Japanese government has appeared to embrace Ramsar's programs such as 'Wise Use of Wetlands' and 'Community Education Participation and Awareness'. Japan's alignment with Ramsar (at least on paper) stands in contrast to its refusal to sign other international laws such as the Convention on Migratory Species due to its strong position on hunting of migratory whales.

As at May 2019, Japan's 52 Ramsar sites place it eighth in the world-behind only the United Kingdom (175 sites), Mexico (142), Spain (75), Sweden (68), Australia (66), Italy (56) and the Netherlands (55) - in terms of the number of internationally recognised wetlands it oversees. The designation of a Ramsar site usually occurs after a site has been declared a 'Wildlife Protection Area' 
or 'Special Protection Area' by the national government (Fletcher et al. 2011, 958). To meet the criteria for a Ramsar site, a nomination must be made by the national government. However, in Japan, Ramsar nomination is complicated by a domestic process which requires local government approval before a wetland can be designated as a Ramsar site (Asano 2014, 52). Therefore, in practice, Ramsar nomination in Japan is largely dependent upon grassroots action, initiated by local governments with the help of wetland NGOs and bird conservation groups.

Fletcher et al. (2011) point out that the "brand" of Ramsar appears to be strong in Japan (958), and empirical evidence points to a certain degree of government effort to implement the overall conservation goals and objectives of Ramsar. The national government, for example, has established a special committee for the implementation of Ramsar (Ramsar Convention Secretariat 2014). As Asano (2014) notes, Ramsar has provided "a catalyst for constructing new relationships between residents and nature" in Japan, particularly around wetland education (61).

\section{National Wetland Policy}

Japan's approach to the Ramsar Convention is also reflected in a sophisticated biodiversity conservation framework at the national level. Whilst there is still no national wetland law in Japan, the MOEJ has created a national wetland policy which forms part of the National Biodiversity Strategy 2012-2020 (日本 の生物多様性国家戦略). At over 300 pages in length, the National Biodiversity Strategy is an ambitious and far-reaching document. It seeks to establish a "roadmap" towards the establishment of "an enriching society" which works "in harmony with nature" (MOEJ 2012, 1). The pursuit of a human-nature connection as articulated in this policy can be seen as consistent with the government's Wanokuni Zukuri sustainability initiative, originally proposed in 2001 (Onodera et al. 2007, 100). ${ }^{7}$ The underlying objective of the initiative at the time was to formally recognise a "harmony" between the Japanese people and their natural environment and make "active efforts" in the restoration of nature (Onodera et al. 2007, 100). It should be noted that this is not unique to Japan: government strategies to promote people living in harmony with nature also exist elsewhere in Asia, most notably in China's efforts to (re)establish an 'ecological civilisation' (Barresi 2017).

The conservation of Japan's rivers and wetlands are referred to in detail in Section 8 of the National Biodiversity Strategy, although tidal mudflats are covered separately in Section 9. The National Biodiversity Strategy singles out tidal wetlands as special areas of concern for the MOEJ. The strategy explicitly acknowledges that many tidal flats and coastal wetlands have been lost through over-development in the post-war era (MOEJ 2012, 30). This has led directly to the decline of organisms living in the tidal zone such as the Japanese Horseshoe Crab (Tachypleus tridentatus; カブトガニ) and the 
Fiddler Crab (Uca arcuata), known in Japanese as shiomaneki (シオマネキ; lit., 'beckoning the return of the tide'). Both the Japanese Horseshoe Crab and Fiddler Crab are now on Japan's endangered species list (MOEJ 2012, 46; Wada et al. 2016). As alluded to above, the decline of these organisms and the loss of the mudflats more generally has contributed to population decline amongst Japan's migratory waterbirds.

More relevantly for the purposes of this paper, the National Biodiversity Strategy also encourages the government and communities to embrace the concept of nature restoration. ${ }^{8}$ The National Biodiversity Strategy sets out a clear vision for addressing decline in coastal and near-shore environments in Japan "through restor[ing] the connection between people and the sea and the rich biotas that are inherent in coastal areas" (MOEJ 2012, 73). Under the National Biodiversity Strategy, which notably utilises the word "restoration" in addition to "conservation" (e.g., MOEJ 2012, 73), over two dozen major wetland restoration projects have already begun in Japan, in places like Fushino River in Yamaguchi prefecture and Kushiro River in Hokkaido (Onodera et al. 2007, 106). Not all restoration projects have been wetland projects, but they often involve a major river or aspect of a river system. Those relating to wetlands are outlined in Appendix 3.

The reference by the MOEJ to 'restoration' in addition to 'protection' and 'conservation' is deliberate. Whereas 'conservation' seeks to maintain the status quo of an ecological system, 'restoration' is far more forward looking. Arguably, this distinction forms a major component of the Japanese government's vision (or at least its rhetoric) of creating harmony between people and nature. A short extract from the National Biodiversity Strategy which demonstrates this is worth reproducing here in full:

Towards the establishment of a society in harmony with nature, it is necessary to renew our appreciation of the value of the natural environment and promote efforts to conserve the natural environment including the flora, fauna and ecosystems endemic to local areas. In addition, it is also necessary that we revive the local natural environment through nature restoration, in an effort to create local communities which can benefit from nature.

(MOEJ 2012, 147)

The restoration commitments made in the National Biodiversity Strategy above do not exist in a policy vacuum. As the next section of this paper shows, they are supported by a broader framework of domestic law and governance around restoration in various contexts in Japan. Earlier legislative initiatives such as an amendment to Japan's River Act (河川法) in 1997 and the introduction of an NGO promotion law in 1998 preceded the 2002 passage of the Nature Restoration Act. As Telesetsky et al. (2017) note, targeted legal arrangements to enable restoration are rare in the world of environmental governance. Aronson et al. (2011) concur, stating that only a handful of nations, including Brazil, South Africa, Namibia, Ecuador, Costa Rica, Vietnam and India, have enacted "public policy and detailed legislation on restoration...[in order to] promote, reward, or enforce 
restoration of degraded ecosystems" (692). Accordingly, Japan is amongst a select group of nations seeking to use law as a tool for encouraging restoration and recovery of its environment. The next section of this paper aligns this move with a possible broader philosophy of recovery and restoration in Japan.

\section{RESTORATION IN JAPAN}

\section{A Restoration Ethos?}

As a nation frequently impacted by earthquakes, typhoons and tsunamis, the idea of restoration could well be said to have become part of Japan's DNA. In its literal translation, 'restoration' (再生) refers to the act or actions of bringing something back to life-for example, by recreating or re-enacting it. Rapid advances in technology have allowed Japan, as it has other nations, to 'recreate' its lost built heritage, damaged as it may have been through war or natural disasters. Some examples of this kind of recovery in Japan, at least in modern times, are its reconstruction efforts after World War II, and its efforts to rebuild cities and towns after natural disasters such as the Great East Japan Earthquake in the Tohoku region (2011) and the Great Kanto Earthquake, which struck Tokyo and surrounds in 1923. ${ }^{9}$ Totman (1989) also describes the way in which the Japanese have mended their relationship with forests in the landscape, noting how periods of considerable deforestation have been followed by state-led initiatives of replanting and recovery. ${ }^{10}$

The interrelationship between law and policy on the one hand, and Japan's experience with restoration on the other, presents an interesting perspective to consider. There is evidence, for instance, that law and a desire for restoration have merged in Japan in some cases. For example, national-level laws have been passed in Japan such as the 2011 Basic Act on Reconstruction in Response to the Great East Japan Earthquake (東日本大震災に対する復興基 本法; hereafter, 'Tohoku Reconstruction Act') which make specific reference to restoring damaged communities and the provision of 'security'. Passed after the Tohoku earthquake (the largest recorded earthquake ever to hit Japan) and resulting tsunami, the law aims to:

create safe communities where preventive measures against damage due to earthquakes and other natural disasters are effective and everyone can enjoy a sense of security for years and decades to come.

(Article 2(v)(a)).

According to Takeuchi et al. (2015), the Great East Japan Earthquake "brought about a major turning point in the question of how to rebuild the relationship between people and nature" (31). This can be seen in the Tohoku Reconstruction Act, which represents not only a legal framework for the

9 It should be acknowledged that there is an ongoing debate around 'recovery efforts' related to the Great East Japan Earthquake in the Tohoku region, as many thousands of evacuees are still in temporary housing. The unintended impact of one government-led reconstruction initiative related to the 2011 earthquake is briefly discussed later; however, a thorough critique or examination of recovery efforts following such a monumental disaster is well outside the scope of this paper. For further reading on recovery following the Great East Japan Earthquake, especially related to governance responses, see Cho (2014). 
mobilisation of government resources, but a broader objective to prevent damage to the physical (built) world and reconsider the relationship between Japan and the natural environment.

A year after the Tohoku Reconstruction Act was enacted, a similar initiative was implemented entitled Special Measures for the Reconstruction and Revitalisation of Fukushima (福島の復興と活性化のための特別措置). The measures aimed, amongst other things, to "facilitate the reconstruction and revitalisation of Fukushima following the nuclear disaster, by establishing basic guidelines for reconstruction and revitalisation of Fukushima" (Article 1). That the language of restoration and revitalisation was included in such laws arguably reflects an ethos of restoration and recovery at the highest levels of government.

\section{Ecological Restoration}

The restoration of the natural world, referred to elsewhere in the literature as 'ecological restoration' (see Telesetsky et al. 2017, 17), brings with it complexities that are different from the built environment. Ecological restoration can be defined as "intentional activity that initiates or accelerates the recovery of an ecosystem with respect to its health, integrity and sustainability" (SER $2004,1)$. This is a similar, although probably not identical, concept to the idea of 'nature restoration' that Japan has promulgated through its recent laws and policies as set out in this paper. The major difference is that the Japanese government does not adopt the terms 'ecosystem' or 'ecology' but instead prefers the term 'nature'.

Semantics aside, there are often complicated value-laden questions surrounding the scale and timing of ecological/nature restoration which first need to be answered (see Akhtar-Khavari and Richardson 2019). These include, for example: what aspects of the environment need to be restored, by whom, and to what ends? The last part of this question raises considerable difficulties for decision-makers. Unlike the reconstruction of a building, for example, adequate resourcing and technology is not always the primary consideration. Attributes and appearances of structures have a fixed point in time to which they can be 'restored'. For example, the revitalisations of Japan's famous castle complexes (e.g., Osaka Castle, Nagoya Castle) reflect Japan's ability to recover its built heritage to a particular point in time. The natural world, on the other hand, is a far more fluid and illusive construct. There is no start or end point to nature, and contemplating a time when an ecosystem was 'healthy' or 'productive' is open to considerable debate.

Despite these challenges, the pursuit of the restoration of nature across the world is not a new phenomenon (Akhtar-Khavari and Telesetsky 2016, 51). Even in Japan, there is some history of attempts to restore rivers, estuaries, rice paddies and other environments (Nakamura et al. 2006, 419). Much of this began in the 1990s, and tended to focus on the recovery of rivers as opposed to other (lesser known) wetland environments like mudflats, marshlands and coral reefs. Between 1990 and 2005, over 23,000 river restoration projects 
were initiated in Japan (Nakamura et al. 2006). These projects were supported by a 1997 amendment to the national River Act (河川法), which provided a formal justification for "improvement of the river environment" (Nakamura et al. 2006, 421). The newly amended River Act, however, had little relevance for the recovery and restoration of tidal flats, marshlands and coral reefs: the river environment, it seems, was the primary focus of Japan's first major policy to recover damaged water-based environments (Nakamura et al. 2006, 421).

More recently in Japan, however, there have been examples of targeted wetland restoration (as opposed to simply river improvement) which have sought to benefit both humans and biodiversity (Tsujii and Sasagawa 2012). Most of the larger wetland projects have been initiated under the Nature Restoration Act (discussed in detail below), which was established five years after the River Act and put wetlands on centre stage. As Nakamura et al. (2006) write, the Nature Restoration Act calls for "a sound scientific underpinning for restoration projects [and] has stimulated countless restoration projects throughout [Japan]," including in relation to wetlands (421).

Many localised wetland restoration projects in Japan now relate to rice paddy environments, which are perhaps the clearest examples of human-biodiversity connections. Indeed, most of these have been initiated or heavily supported at a local level by farming communities and local governments (Tsujii and Sasagawa 2012). For example, in Miyagi prefecture's Osaki City, a method of farming known as fuyumizu-tambo (冬水田んぼ; lit., 'winter water rice field') - which involves submerging rice fields throughout the winter offseason-encourages farmers to cultivate rice without any chemical pesticides or fertilisers. Where fuyumizu-tambo is not practiced, rice paddies are drained in the winter months to encourage nitrogen in the soil; this practice has the effect of killing microorganisms and deterring visiting birdlife (Tsujii and Sasagawa, 2012, 6). In contrast, where fuyumizu-tambo is practiced, paddy wetlands are 'restored' by allowing water to remain in the paddies through both summer and winter, at the same time providing additional habitat for over 130,000 migrating geese to Miyagi each year (Tsujii and Sasagawa 2012, 6).

From a governance perspective, it is advantageous for these types of restoration projects (for wetlands, rivers or otherwise) to be supported by law. Passing laws which allow for restoration has the advantage of controlling practical issues such as insurance, financing, provision of machinery, transparency in decision-making, and issuing of permits (to enter private or public land). The law can also set out basic principles or objectives for how the restoration is to occur. A good example of a law created specifically for ecological restoration is that of Japan's Nature Restoration Act, introduced above and covered in more detail in the next section.

\section{Act for the Promotion of Nature Restoration (Nature Restoration Act)}

Japan's Nature Restoration Act (2002) aims to encourage restoration of the natural environment. There is an accompanying policy to the law which sets out further detail to the government's approach (MOEJ n.d.[c]). Before the 
law was passed in 2002, there was disagreement amongst Japanese politicians about what exactly it should seek to achieve. As Onodera et al. (2007) recall, "the biggest argument was [whether] nature restoration was just another public project [in Japan] with a different name" (111). In Japan, as elsewhere, laws have the effect of binding government decision-makers to ensure that their actions are accountable through the courts. Accordingly, it has been argued that the passage of a nature restoration law in Japan will help to ensure "nature restoration projects [form] a solid movement for years to come" (Onodera et al. 2007, 100).

The major impetus for Japan's Nature Restoration Act can be traced to the national government's engagement with international agreements like the Convention on Biological Diversity and the Ramsar Convention in the 1990s. As Telesetsky et al. (2017) remark, the idea of nature restoration has been a keen interest of many countries, becoming a regular theme "at nearly every [Convention on Biological Diversity] conference” (130). In 1996, for example, all parties under the Convention on Biological Diversity, including Japan, agreed to "take action[s] to achieve the restoration of habitats including their biological diversity component" (Telesetsky et al. 2017, 130). At the same time, ecological restoration was being pursued under the Ramsar framework. Although the original 1971 text of Ramsar made no mention of restoration, the COP in 1990 urged all members to undertake wetland restoration (Telesetsky et al. 2017, 96). Three years later, at the Kushiro COP in 1993, member states including Japan agreed to intensify their focus on wetland restoration with a view to delivering benefits for both humans and biodiversity (Telesetsky et al. 2017, 96). Accordingly, Japan's Nature Restoration Act is not an isolated initiative. It reflects a longer engagement with the international community through both the Convention on Biological Diversity and the Ramsar Convention surrounding the concept of restoration.

\section{What does the Nature Restoration Act do?}

Responding to international best practice, as exemplified by the Convention on Biological Diversity and the Ramsar Convention, the Nature Restoration Act essentially provides a framework to allow for and encourage the practices of ecological restoration in Japan. Article 3 of the law sets out the basic 'principles' by which restoration is to occur, summarised as follows: (1) restoration should occur in cooperation with a range of government and non-government stakeholders; (2) restoration should be based upon sound scientific knowledge; and (3) restoration should be aligned with community participation and educational activities. These principles are further reflected in MOEJ's Basic Policy for Nature Restoration (自然再生の ための基本方針), which also highlights the need for an 'adaptive management' approach (MOEJ n.d.[c]).

The link between Japan's Nature Restoration Act and international law is evident in these principles. The reference to scientific knowledge (principle 2 above), for example, broadly reflects the goals of the 'precautionary principle,' a concept which maintains that decisions should be based upon, and

(n)


justified by, the best available science (de Sadeleer 2010). More specifically, the principle is meant to ensure that, in the absence of scientific knowledge, actions to protect the environment should not be postponed. In other words, where threats to the environment are unknown, decision-makers should err on the side of caution. Similarly, the principle of 'public participation', also a principle under international environmental law (Sands and Peel 2018), is clearly reflected in the Nature Restoration Act through principle (3) above. The desire for the public to be involved is also articulated in the MOEJ's Basic Policy on Restoration which accompanies the law:

In the implementation of a nature restoration project, it is important to have the participation and cooperation of various actors in the region, including the concerned governmental agencies, concerned local governments, local residents, specified non-profit corporations and other civil organisations... and individuals with specialised knowledge of the natural environment, from the initial stage of formulating the concept of the nature restoration project, designing surveys, and implementing the project, to maintenance after the project has been implemented.

(MOEJ n.d.[c])

Seen against the background of earlier discussions, these examples show how Japan's environmental law dovetails with international governance frameworks while also achieving cohesion with domestic legislation (through its restoration ethos) and fostering grassroots participation and engagement (by localising the nomination of Ramsar sites, among other measures). In doing so, Japan's environmental laws have laid the groundwork for crosssector collaboration on numerous significant nature restoration projects that have been spearheaded by local governments (often in conjunction with NGOs), are endorsed and funded by the national government, and are increasingly integrated with global environmental agreements. The sections below discuss how these collaborations manifest in practice and examine the provisions for them within the law.

\section{How are Nature Restoration Projects Implemented in Japan?}

After establishing the basic principles above, derived as they have been from international environmental law, the Nature Restoration Act goes on to outline the responsibilities of both national and local governments in Japan, requiring them to act as facilitators or supporters of restoration projects (Article 4). Thereafter, article 5 turns our attention to the "effectors" (or 'implementers') of nature restoration projects which include NGOs, private corporations and other non-state actors. The law states that a committee system is to be established for each restoration project which includes both governmental and non-government stakeholders (Article 8), and that special consideration is given for how permits and other "legally prescribed" activities should occur to ensure "smooth and speedy" implementation of projects (Article 12). Each project requires an "implementation plan" which is subject to the approval of the MOEJ, the Ministry of Agriculture, Forestry and Fisheries (MAFF) and the Ministry of Land, Infrastructure, Transport and Tourism (MLIT). The resulting process is outlined in Figure 2 (below).

(n)




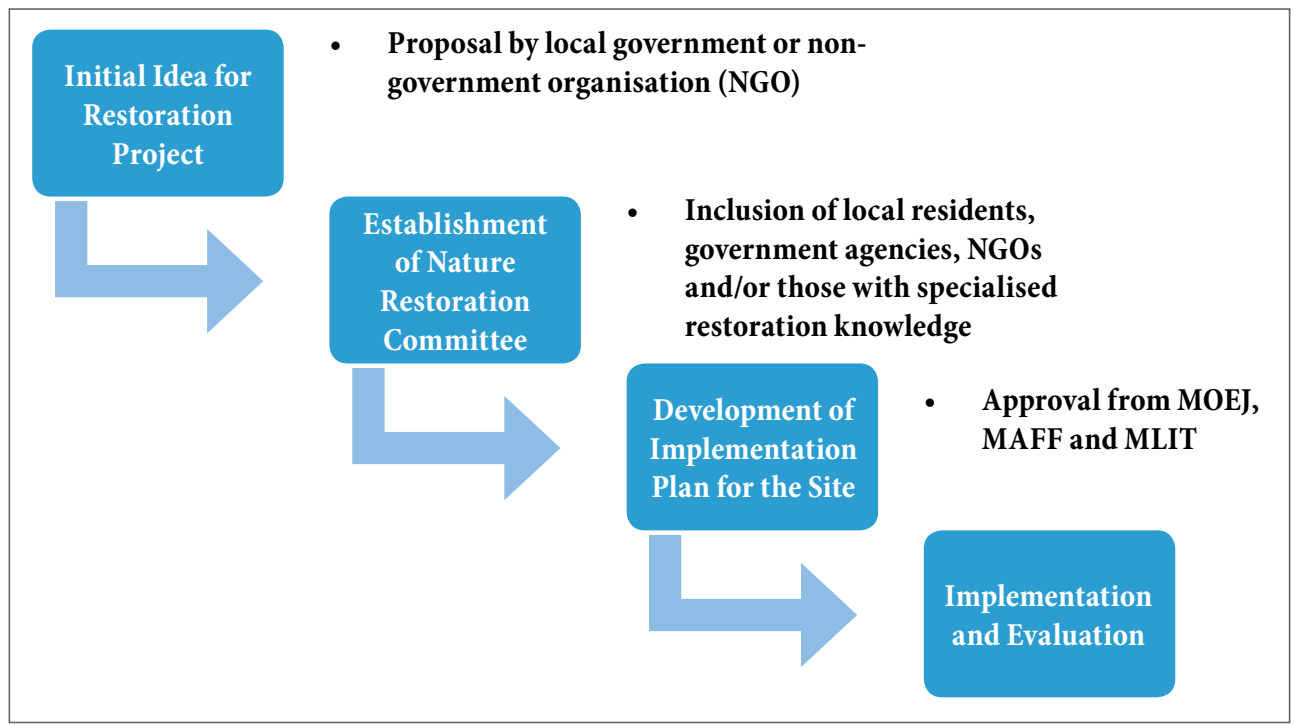

Figure 2: An illustration of the staged process from conceptualisation of a restoration project under the Nature Restoration Act through to implementation and evaluation

\section{What Kinds of Projects have been Implemented under the Law?}

Approximately half of the restoration projects that have been established since the Nature Restoration Act was passed in 2002 relate to wetlands in some way (the others concern grasslands, coral reefs and forested areas). Examples of major wetland restoration projects initiated under the law, including the causes of degradation and restorative measures, are set out in Appendix 3. Most of the wetland projects have been driven by municipal governments, with only two (Kushiro and Sarobetsu) driven at the national level (MOEJ 2009). This indicates the extent to which grassroots involvement is crucial to nature restoration in Japan. The national government has formulated policy to support nature restoration, but rarely spearheads restoration projects. Therefore, in practical terms, it can be argued that community awareness, engagement and action are equally important to the wellbeing of Japan's natural environment as its national-level policy architecture.

\section{TOWARDS EFFECTIVE WETLAND RESTORATION: WHERE TO FROM HERE?}

\section{Meaningful Participation of Local Communities}

Under the Nature Restoration Act, the Japanese government makes provisions for 'the state' (including prefectural and local governments in Japan) to play a cooperative role in restoration. The main collaborators in restoration projects are intended to be NGOs, scientists, universities and the Japanese private sector. A stated distinction in the law between 'governments' and 'effectors' makes the desire for collaboration clear. By a similar token, specific reference is made in the law to Article 2 of the 1998 Act to Promote Specified NonProfit Activities in Japan (特定非営利活動促進法), ostensibly with the aim of harnessing and leveraging the "specialized [restoration] knowledge" of those in the NGO and private sector.

(n)


All of this reflects an explicit attempt to establish a collaborative governance approach to nature restoration in Japan. The phrase 'collaborative governance' is well covered in the broader governance literature and in environmental matters is often considered best practice in achieving conservation goals (Gunningham 2009; Bodin 2017). Collaborative governance is a broad concept and may be defined as follows:

A governing arrangement where one or more public agencies directly engage non-state stakeholders in a collective decision-making process that is formal, consensus-oriented, and deliberative and that aims to make or implement public policy or manage public programs or assets.

(Ansell and Gash 2008, 544)

Ansell and Gash's (2008) definition describes three elements of a collaborative framework: (1) an initiative driven first and foremost by a public agency (e.g., the MOEJ); (2) an initiative which is formal but also consensus-driven (e.g., established through rules, laws or written processes); and (3) an initiative which aims to implement a public program or policy (e.g., wetlands restoration). At face value, Japan's Nature Restoration Act satisfies each of these three elements, providing a further example of its dovetailing with internationally recognised best practice.

However, the effective implementation of collaborative restoration is another question. Rushed efforts to revive natural environments without appropriate expertise, public inclusion or robust assessment of long-term impacts can result in poor socio-ecological outcomes, and there are lessons to be learnt from examples akin to this in Japan. In the case of restoration efforts in the tsunami zone following the Great East Japan Earthquake, for instance, 40foot seawalls were built in Iwate prefecture. The walls were intended to stop any future tidal surges or tsunamis, but many locals have claimed feeling like they are "in jail" (Jacobs 2018). In this way, 'restorative measures' which were ostensibly pursued in the public interest have carved a rift between local communities and the natural seascapes upon which their pre-disaster livelihoods may have depended.

In another example of restoration efforts with unintended consequences, the mass replanting of the Japanese countryside with cedar (Cryptomeria japonica; 杉) forests in the 1950s, 1960s and 1970s in response to deforestation resulted in an "annual allergy epidemic" in Japan due to increased pollen in the air (Singleton 2015). These cedar-dominated landscapes have also depleted the original richness of the natural forests, causing Japanese Black Bears (Ursus thibetanus japonicus; ツキノワクマ) to venture closer to the villages in search of food and thereby causing conflict with humans (Knight 2007). In 2006, over 4,500 bears were culled in the name of human protection (Knight 2007, 5), and across Japan, the phenomenon is now referred to as "kuma mondai," or "the bear problem" (6).

As these examples illustrate, human interventions into ecosystems in the name of restoration can result in perverse socio-ecological outcomes, such as biodiversity loss and/or the isolation of local communities that 
rely on wetlands for their livelihoods. Interventions into ecosystems (as socio-ecological landscapes) that are designed and implemented in close consultation with those who live or rely on them and are backed by the best available science are arguably likely to reduce these problems. The challenge, therefore, is to design and implement effective models of collaborative governance. As Bodin (2017) writes:

addressing the issue [of collaboration] is clearly not as simple as just establishing collaboration among a large set of actors and stakeholders, and then all will be well. Rather, the questions are when and how collaboration is effective, for what kind of environmental problems is it useful, and if and how this relates to the temporal and spatial characteristics of the governed ecosystems.

(1)

To achieve this may require a deeper level of thinking around how, where and why people live within certain wetland landscapes in Japan. It is to those considerations we now briefly turn.

\section{Integrating Wetland Restoration within Existing Socio-Ecological Landscapes}

The concepts of satoyama and satoumi have been and continue to be integral to wetland and coastal management in Japan. In Japanese, 'sato' (里) means 'village', 'yama' (山) means 'mountain' and 'umi' (海) means 'sea'. Thus, 'satoyama' refers to the area of land between the mountain and the village (i.e., the landscape), whilst 'satoumi' refers to the area between the village and the sea (i.e., the seascape). Both satoyama and satoumi are classified as "socioecological production landscapes" under international law (Secretariat of the Convention on Biological Diversity 2011, 73) and have been formally recognised as positive drivers of sustainability in the Japanese Government's National Biodiversity Strategy.

Sadly, both satoumi and satoyama have been declining in recent years due to increased urbanisation, infrastructure development and the loss of connection between people, their traditional farming methods and the natural world (Duraiappah et al. 2012). In some cases, entire villages have withdrawn from rice paddy cultivation, leaving them to dry out, which has had flow-on effects for wetlands. For example, in the area of Eastern Kosado (小佐渡東 部) in Niigata prefecture, the abandonment of traditional rice terraces due to aging farmers and mechanised production has seen declines in local birdlife which has come to rely on the area (MOEJ 2009, 29). Takeuchi et al. (2015) summarise the satoyama problems Japan is facing as follows:

...abandonment of farmland and neglect of forests and agricultural facilities are ongoing due to depopulation (particularly aging and desertion in rural areas), changes in industrial structures, and dependency on external agricultural products and energy, leading to underuse of domestic natural resources, which is affecting the natural environment and biodiversity. 
In recent times, the national government has introduced efforts to reinvigorate landscapes like satoumi and satoyama. Japan was instrumental, for instance, in launching the International Partnership for the Satoyama Initiative (SATOYAMA イニシアティブ国際パートナーシップ) in 2010 (MOEJ 2012,17 ), which is now comprised of 253 member organisations striving to realise a global society 'in harmony with nature' (IPSI 2019). However, while satoyama has been recognised within Japan's Nature Restoration Act (Article 2), no major projects to date-with the possible exception of the restoration of the Eastern Kosado wetlands (see Appendix 3) - have specifically aimed to revitalise satoyama landscapes (MOEJ 2009).

This suggests that more needs to be done to extend legal frameworks for nature restoration to include degraded or under-utilised wetland landscapes. There are ample opportunities to drive this under the Ramsar Convention's 'Wise Use' concept, and indeed, there are numerous examples of Japan encouraging the sustainable use of resources by people in its wetlands (Tsujii and Sasagawa 2012). However, at present, there appear to have been no meaningful attempts to establish wetland restoration projects that revitalise satoyama or satoumi landscapes under the law. This likely requires a more sophisticated administrative approach by the government, or, as Takeuchi et al. (2015) write, "[it requires] policies [that] deal with issues in interconnected and coupled systems" (38). However, a look at Japan's existing environmental law suggests that new policies need not be formulated. There are ample opportunities within the current legal framework to revitalise satoyama and satoumi environments; what is needed is an administrative vision which more deeply connects Japan's wetlands to their "functional relationships among different [landscape] production activities ... [such as] forestry, agriculture and fisheries." (Takeuchi et al. 2015, 35). In short, landscape-scale approaches to wetland restoration are required.

\section{CONCLUSION}

Japan's spectacular economic growth in the post-war era resulted in severe degradation of its wetland environments. As a consequence, biodiversity has experienced declines. Japan's wetlands need to be restored and enhanced in order to replenish and enliven their value to wildlife and society. I argue that this can be achieved through increased cross-sector and community collaboration which is centred on an awareness of traditional landscape uses and harnesses traditional cultural practices. The government of Japan has recognised the extent of wetland degradation and sought to establish a 'harmony' between people and nature through the law.

The passage of the Nature Restoration Act in 2002 was a landmark moment for Japan. At its heart, this law is about collaborative governance; that is, the partnering of NGOs, governments and private institutions to carry out restoration work. Over two dozen major projects have already been initiated under the Nature Restoration Act, including several major works relating to wetlands. Ultimately, Japan is a nation well-placed to restore its wetlands 
because of its history of recovery in other areas and its sophisticated legal framework which lays the foundations for such measures to occur. However, to realise the Act's goals, greater efforts are needed to focus attention at the landscape scale and further involve local communities in restorative works.

\section{GLOSSARY}

\section{COP}

'Conference of the [Ramsar] Contracting Parties'; the name given to the triennial meetings related to the Ramsar Convention, where the listing of wetland sites is resolved and mechanisms for conservation and restoration are discussed. COPs are attended by delegates of nations that are signatories to Ramsar, as well as relevant NGOs.

\section{EAAF}

East Asian-Australasian Flyway; one of nine major routes travelled annually by migratory birds, stretching from New Zealand and Australia in the south to Russia and the United States (Alaska) in the north.

\section{EAAF Partnership}

A non-binding arrangement to conserve migratory waterbirds sites throughout the EAAF, with 18 member nations as at June 2019

\section{Fuyumizu-tambo (冬水田んぼ)}

Also, fuyumizu-tanbo. Lit., 'winter water rice field'; the agricultural practice of submerging ricefields throughout the winter off-season, which allows rice to be cultivated without the use of chemical pesticides or fertilisers.

\section{Higata (干潟)}

Tidal mud flats

\section{IPSI}

International Partnership for the Satoyama Initiative; a global project with 253 member states, led by Japan, with the aim of reinvigorating satoumi- and satoyamatype landscapes.

\section{MAFF}

Ministry of Agriculture, Forestry and Fisheries, Japan

\section{MILT}

Ministry of Land, Infrastructure, Transport and Tourism, Japan

\section{MOEJ}

Ministry of the Environment, Japan

\section{Ramsar Convention}

The main international treaty governing wetland conservation, established in 1971

\section{Satoumi (里海)}

The area between a village and the sea (i.e., the seascape). Satoumi areas, like their satoyama counterparts, are classified as 'socio-ecological production landscapes' under international law. The satoumi and satoyama concepts have been and continue to be integral to wetland management in Japan. 
The area between a village and the mountains (i.e., the landscape). For further

information, see satoumi (above).

Wanokuni Zukuri (『環の国』づくり)

The name of a sustainability initiative proposed by the Japanese government in 2001, which can be variously translated as 'developing our nation,' 'developing an environmental [eco-friendly] nation' and 'developing a harmonious nation.'

\section{Appendix 1. Japanese and International Environmental Governance Frameworks Cited}

\section{Japanese}

Act for the Promotion of Nature Restoration, 2002 (Nature Restoration Act)

自然再生推進法

National Biodiversity Strategy 2012-2020 (incorporates the national wetland policy) 日本の生物多様性国家戦略

River Act, 1997 amendment

河川法

Basic Act on Reconstruction in Response to the Great East Japan Earthquake, 2011 (Tohoku Reconstruction Act)

東日本大震災に対する復興基本法

Special Measures for the Reconstruction and Revitalisation of Fukushima 福島の復興と活性化のための特別措置

Basic Policy for Nature Restoration

自然再生のための基本方針

Act to Promote Specified Non-Profit Activities in Japan, 1998 (Article 2)

特定非営利活動促進法

Wanokuni Zukuri, 2001

『環の国』づくり

\section{International}

Convention on Biological Diversity

生物多様性に関する条約

Convention on Migratory Species

移動性野生動物種の保全に関する条約

East Asian-Australasian Flyway Partnership (EAAF Partnership)

東アジア・オーストラリア地域フライウェイパートナーシップ (EAAFパートナーシップ)

International Partnership for the Satoyama Initiative

SATOYAMA イニシアティブ国際パートナーシップ 


\section{Appendix 2. Examples of Rice Fields as Bird Habitat in Lake Biwa}
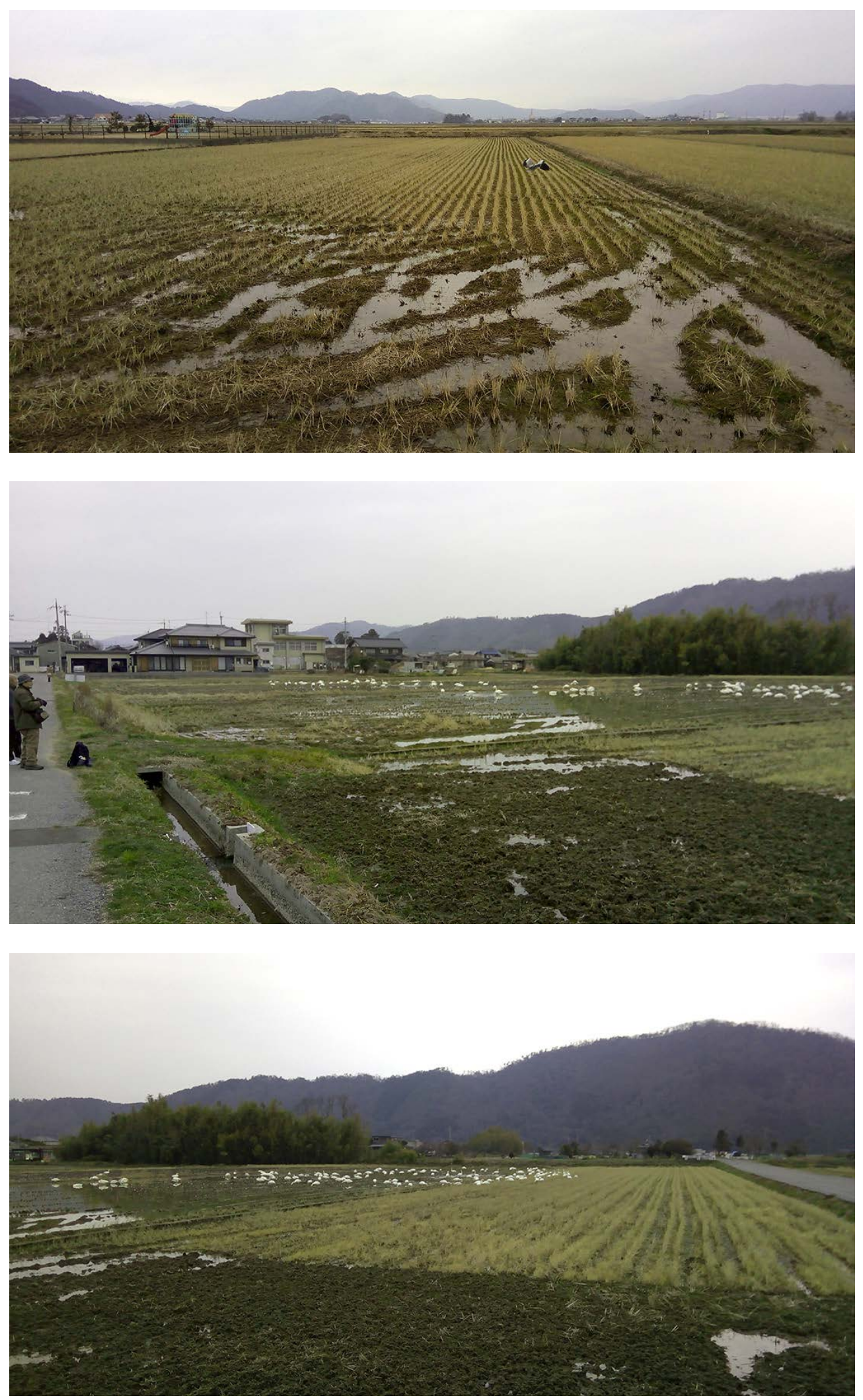

Figure 1 (top), Figure 2 (centre) and Figure 3 (bottom): Rice fields provide important habitat for birdlife in the wetlands adjacent to Lake Biwa. 


\section{Appendix 3. Examples of Major Wetland Restoration Projects in Japan Undertaken in Accordance with the Nature Restoration Act}

\begin{tabular}{|c|c|c|c|c|c|}
\hline $\begin{array}{l}\text { Name of Wetland } \\
\text { (and Location) }\end{array}$ & $\begin{array}{l}\text { Sponsoring } \\
\text { Authority }\end{array}$ & $\begin{array}{l}\text { Ramsar } \\
\text { Status }\end{array}$ & $\begin{array}{l}\text { EAAFP } \\
\text { Status }\end{array}$ & Causes of Degradation & Restorative Measures \\
\hline $\begin{array}{l}\text { Kushiro Wetland } \\
\text { (Kushiro, Hokkaido) }\end{array}$ & MOEJ & $\begin{array}{l}\text { Listed } \\
\text { (1980) }\end{array}$ & $\begin{array}{l}\text { Listed } \\
\text { (1997) }\end{array}$ & $\begin{array}{l}\text { - Encroachment and irrigation } \\
\text { of agricultural lands } \\
\text { neighbouring the site } \\
\text { - Diversion of the Kushiro } \\
\text { River for irrigation and } \\
\text { flood control }\end{array}$ & $\begin{array}{l}\text { - Erosion control } \\
\text { - Raising of the groundwater } \\
\text { table } \\
\text { - Replanting of wetland } \\
\text { vegetation } \\
\text { - Restoring the Kushiro River to } \\
\text { natural (meandering) flow }\end{array}$ \\
\hline $\begin{array}{l}\text { Sarobetsu } \\
\text { (Teshio-gun, } \\
\text { Hokkaido) }\end{array}$ & MOEJ & $\begin{array}{l}\text { Listed } \\
\text { (2005) }\end{array}$ & Not Listed & $\begin{array}{l}\text { - Decades of peat mining } \\
\text { lover } 150 \text { ha of wetlands } \\
\text { lostl }\end{array}$ & $\begin{array}{l}\text { - Rehabilitation of wetland } \\
\text { vegetation in abandoned } \\
\text { peat mining areas } \\
\text { - Establishment of buffer zones } \\
\text { and retention ponds }\end{array}$ \\
\hline $\begin{array}{l}\text { Gamo Tidal Flat } \\
\text { (Sendai, Miyagi } \\
\text { prefecture) }\end{array}$ & $\begin{array}{l}\text { Municipal } \\
\text { Government }\end{array}$ & Not Listed & Not Listed & $\begin{array}{l}\text { - Impacted by construction of } \\
\text { Sendai Port and river } \\
\text { engineering work } \\
\text { - Sand incursions from the } \\
\text { ocean causing detriment } \\
\text { and poor water flow to/from } \\
\text { site }\end{array}$ & $\begin{array}{l}\text { - Sand transport control } \\
\text { - Channel dredging }\end{array}$ \\
\hline $\begin{array}{l}\text { Sanbanze } \\
\text { (Urayasu, Ichikawa, } \\
\text { Funabashi and } \\
\text { Narashino, Chiba } \\
\text { prefecture) }\end{array}$ & $\begin{array}{l}\text { Municipal } \\
\text { Government }\end{array}$ & Not Listed & Not Listed & $\begin{array}{l}\text { - Increased landfill, } \\
\text { subsidence and erosion } \\
\text { - Pollution from wastewater }\end{array}$ & $\begin{array}{l}\text { - Expansion of tidal flat area } \\
\text { - Tidal flushing } \\
\text { - Filling deep areas } \\
\text { - Enhancing freshwater flow }\end{array}$ \\
\hline $\begin{array}{l}\text { Lake Izunuma- } \\
\text { Uchinuma } \\
\text { (Tome and Kurihara, } \\
\text { Miyagi prefecture) }\end{array}$ & $\begin{array}{l}\text { Municipal } \\
\text { Government }\end{array}$ & $\begin{array}{l}\text { Listed } \\
\text { [1985) }\end{array}$ & $\begin{array}{l}\text { Listed } \\
\text { (2014) }\end{array}$ & $\begin{array}{l}\text { - Development of irrigation } \\
\text { and flood-water retention } \\
\text { ponds } \\
\text { - Several years of heavy } \\
\text { rainfall }\end{array}$ & $\begin{array}{l}\text { - Growing and transplanting } \\
\text { emergent and submersed plants } \\
\text { - Breeding and transferring } \\
\text { native fish and mussels }\end{array}$ \\
\hline $\begin{array}{l}\text { Eastern Kosado } \\
\text { (Sado, } \\
\text { Niigata prefecture) }\end{array}$ & $\begin{array}{l}\text { Municipal } \\
\text { Government }\end{array}$ & Not Listed & Not Listed & $\begin{array}{l}\text { - Abandonment of } \\
\text { surrounding rice paddies } \\
\text { - Lack of care for surrounding } \\
\text { forests }\end{array}$ & $\begin{array}{l}\text { - Planting of wetland vegetation } \\
\text { and improving water flows } \\
\text { - Reintroduction of water birds, } \\
\text { such as Japanese Crested Ibis }\end{array}$ \\
\hline $\begin{array}{l}\text { Lake Biwa } \\
\text { (Nagahama and } \\
\text { Kohoku, Shiga } \\
\text { prefecture) }\end{array}$ & $\begin{array}{l}\text { Municipal } \\
\text { Government }\end{array}$ & $\begin{array}{l}\text { Listed } \\
\text { [1993] }\end{array}$ & $\begin{array}{l}\text { Listed } \\
\text { (1999) }\end{array}$ & $\begin{array}{l}\text { - Land reclamation of lagoon } \\
\text { areas } \\
\text { - Declines in reed covers and } \\
\text { riparian forests through } \\
\text { urban use/encroachment }\end{array}$ & $\begin{array}{l}\text { - Flooding of reclaimed land } \\
\text { - Installation of walls and jetties } \\
\text { to stabilise sediment }\end{array}$ \\
\hline $\begin{array}{l}\text { Yawata Wetlands } \\
\text { (Kitahiroshima, } \\
\text { Yamagata-gun, } \\
\text { Hiroshima } \\
\text { prefecture) }\end{array}$ & $\begin{array}{l}\text { Municipal } \\
\text { Government }\end{array}$ & Not Listed & Not Listed & $\begin{array}{l}\text { - Drainage of wetlands, } \\
\text { primarily due to pastoral } \\
\text { agriculture }\end{array}$ & $\begin{array}{l}\text { - Rehabilitation of wetland } \\
\text { vegetation and control of } \\
\text { invasive species } \\
\text { - Removing the drainage canal, } \\
\text { installation of levees }\end{array}$ \\
\hline $\begin{array}{l}\text { Harima Irrigation } \\
\text { Ponds } \\
\text { (Ono, Kasai and } \\
\text { Kato, Hyogo } \\
\text { prefecture) }\end{array}$ & $\begin{array}{l}\text { Municipal } \\
\text { Government }\end{array}$ & Not Listed & Not Listed & $\begin{array}{l}\text { - Decrease in size of pond } \\
\text { areas } \\
\text { - Reduced water quality from } \\
\text { invasion of alien species }\end{array}$ & $\begin{array}{l}\text { - Removal of rodents } \\
\text { - Removing lotus and reducing } \\
\text { dense reed coverage }\end{array}$ \\
\hline $\begin{array}{l}\text { Fushino River Tidal } \\
\text { Flats } \\
\text { (Yamaguchi, } \\
\text { Yamaguchi } \\
\text { prefecture) }\end{array}$ & $\begin{array}{l}\text { Municipal } \\
\text { Government }\end{array}$ & Not Listed & Not Listed & $\begin{array}{l}\text { - Eutrophication from } \\
\text { upstream agricultural and } \\
\text { urban uses } \\
\text { - Oyster overpopulation due } \\
\text { to enrichment of estuarine } \\
\text { water } \\
\text { - Compaction of mud flat and } \\
\text { decline of eelgrass }\end{array}$ & $\begin{array}{l}\text { - Shell crushing and ploughing in } \\
\text { high-density areas of oyster } \\
\text { shells } \\
\text { - Ploughing in the sandy areas }\end{array}$ \\
\hline $\begin{array}{l}\text { Kashibaru Wetlands } \\
\text { (Karatsu, Saga } \\
\text { prefecture) }\end{array}$ & $\begin{array}{l}\text { Municipal } \\
\text { Government }\end{array}$ & Not Listed & Not Listed & $\begin{array}{l}\text { - Road construction } \\
\text { - Agricultural practices } \\
\text { lincluding cessation of field } \\
\text { burningl }\end{array}$ & $\begin{array}{l}\text { - Increasing open water supply } \\
\text { - Dredging } \\
\text { - Removal of dead vegetation }\end{array}$ \\
\hline
\end{tabular}

Source: MOEJ (2009). Note: All sites in this table are included in the MOEJ's list of Japan's 


\section{REFERENCES}

Akhtar-Khavari, A. and B. Richardson. 2019. Ecological Restoration Law Concepts and Case Studies. Oxford: Routledge.

Akhtar-Khavari, A. and A. Telesetsky. 2016. "From Protection to Restoration: A Challenge for Environmental Governance." In Research Handbook on Fundamental Concepts of Environmental Law, edited by D. Fisher, 50-81. Cheltenham: Edward Elgar Publishing. https://doi.org/10.4337/9781784714 659.00009 .

Amano, T., T. Szekely, K. Koyama, H. Amano and W. J. A. Sutherland. 2010. "A Framework for Monitoring the Status of Populations: An Example from Wader Populations in the East Asian-Australasian Flyway." Biological Conservation 143 (9): 2238-47. https://doi.org/10.1016/j.biocon.2010.06.010.

Ansell, C. and A. Gash. 2008. "Collaborative Governance in Theory and Practice." Journal of Public Administration Research and Theory 18 (4): 543-71. https:// doi.org/10.1093/jopart/mum032.

Aronson, J., et al. 2011. "What Role Should Government Regulation Play in Ecological Restoration? Ongoing Debate in Sao Paulo State, Brazil." Restoration Ecology 19 (6): 690-95. https://doi.org/10.1111/j.1526-100X. 2011.00815.x.

Asano, T. 2014. "International Nature Reserves and Local Inhabitants: The Case of the 'Wise Use' of Ramsar Wetlands in Japan." Japanese Journal of Human Geography 66 (6): 48-63. https://doi.org/10.4200/jjhg.66.6_536.

Barresi, P. 2017. “The Role of Law and the Rule of Law in China's Quest to Build an Ecological Civilisation." Chinese Journal of Environmental Law 1 (1): 9-36. https://doi.org/10.1163/24686042-12340003.

Birdlife International. 2017. "Numenius madagascariensis (amended version of 2016 assessment)." The IUCN Red List of Threatened Species 2017: e.T22693199 A118601473. Accessed 13 June, 2019. https://doi.org/10.2305/IUCN.UK. 2017-3.RLTS.T22693199A118601473.en.

Bodin, Ö. 2017. "Collaborative Environmental Governance: Achieving Collective Action in Social-Ecological Systems." Science 357 (6352): eaan1114. https:// doi.org/10.1126/science.aan1114.

Cho, A. 2014. "Post-Tsunami Recovery and Reconstruction: Governance Issues and Implications of the Great East Japan Earthquake.” Disasters 38 (s2): s15778. https://doi.org/10.1111/disa.12068.

Davidson, N. 2014. "How Much Wetland has the World Lost? Long-Term and Recent Trends in Global Wetland Area." Marine and Freshwater Research 65 (10): 934-41. https://doi.org/10.1071/MF14173.

de Sadeleer, N. 2010. "The Precautionary Principle in EU Law." Aansprakelijkheid Verzekering En Schade 5: 173-84. 
Dempster, P. 1967. Japan Advances: A Geographical Study. London: Methuen.

Duraiappah, A. K., K. Nakamura and K. Takeuchi. 2012. Satoyama-Satoumi Ecosystems And Human Well-Being: Socio-Ecological Production Landscapes Of Japan. Tokyo: United Nations University Press.

EAAF Partnership. n.d. 'Migratory Waterbirds, Far Eastern Curlew," EAAFP. Accessed 19 October, 2018. https://eaaflyway.net/migratory-waterbirds/fareastern-curlew/.

Endoh, T. 2004. "Historical Review of Reclamation Works in the Tokyo Bay Area." Journal of Geography (Chigaku Zasshi) 113 (6): 785-801. https://doi.org/ 10.5026/jgeography.113.6_785.

Eyre, J. 1956. "Japanese Land Development in Kojima Bay." Economic Geography 32 (1): 58-74. https://doi.org/10.2307/141931.

Fletcher, S., M. Kawabe and S. Rewhorn. 2011. "Wetland Conservation and Sustainable Coastal Governance in Japan and England." Marine Pollution Bulletin 62 (5): 956-62. https://doi.org/10.1016/j.marpolbul.2011.02.048.

Fujioka, M., S. Lee, M. Kurechi and H. Yoshida. 2010. "Bird Use of Rice Fields in Korea and Japan.” Waterbirds 33 (1): 8-29. https://doi.org/10.1675/063.033. s102.

Fujita, H., Y. Igarashi, S. Hotes, M. Takada, T. Inoue, and M. Kaneko. 2009. “An Inventory of the Mires of Hokkaido, Japan: Their Development, Classification, Decline, and Conservation." Plant Ecology 200 (1): 9-36. https://doi.org/10.1007/s11258-007-9267-z.

Gunningham, N. 2009. "The New Collaborative Environmental Governance: The Localization of Regulation." Journal of Law and Society 36 (1): 145-66. https://doi.org/10.1111/j.1467-6478.2009.00461.x.

Haidary, A., B. J. Amiri, J. Adamowski, N. Fohrer and K. Nakane. 2013. "Assessing the Impacts of Four Land Use Types on the Water Quality of Wetlands in Japan." Water Resources Management 27 (7): 2217-29. https://doi. org/10.1007/s11269-013-0284-5.

Hamman, E. 2018. "Cultural Perceptions and Natural Protections: A Socio-Legal Analysis of Public Participation, Birdlife and Ramsar Wetlands in Japan." Asia Pacific Journal of Environmental Law 21: 4-28. https://doi.org/10.4337/ apjel.2018.01.01.

Hong, J. K. and Iisaka, J. 1982. "Coastal Environment Change Analysis by Landsat MSS Data” Remote Sensing of Environment 12 (2): 107-16. https:// doi.org/10.1016/0034-4257(82)90030-X.

Ichikawa, H. 1994. “The Evolutionary Process of Urban Form in Edo/Tokyo to 1900." The Town Planning Review 65 (2): 179-96. https://doi.org/10.3828/ tpr.65.2.j81596x50p367031. 
Ichikawa, T., M. Yasuda, T. Nuka, T. Moriya, M. Kashiwagi, K. Chen and T. Shibahara. 2017. "Population Decline of Migratory Waterbirds and Habitat ChangesShorebirds as Indicators." In Proceedings of the 8th Asian Wetland Symposium, Saga, Japan, 7-11 November. http://aws2017.org/documents/ proceedings.pdf.

IPSI (International Partnership for the Satoyama Initiative). 2019. "Concept," International Partnership for the Satoyama Initiative. Accessed 1 March, 2019. https://satoyama-initiative.org/about/.

Jacobs, S. 2018. “It Feels Like We're in Jail': Japan Spent $\$ 12$ Billion on Seawalls After the Devastating 2011 Tsunami-and now Locals are Feeling like Prisoners." Business Insider, 12 March. Accessed 1 March, 2019. https://www.businessinsider.com/japan-seawalls-cost-12-billion-sincefukushima-disaster-2018-3/.

Japan Times, The. 2001. "500 Important Wetlands Named in National Biodiversity Plan.” The Japan Times, 12 October. Accessed 20 June, 2019. https://www. japantimes.co.jp/news/2001/10/12/national/500-important-wetlandsnamed-in-biodiversity-plan/.

Knight, C. 2007. The Bear as a Barometer: The Japanese Response to Human-Bear Conflict.Doctoral thesis, The University of Canterbury. https://ir.canterbury. ac.nz/bitstream/handle/10092/991/thesis_fulltext.pdf?sequence $=1$ \&isAllowed $=\mathrm{y}$.

Koh, C. H. and V. de Jonge. 2014. "Stopping the Disastrous Embankments of Coastal Wetlands by Implementing Effective Management Principles: Yellow Sea and Korea Compared to the European Wadden Sea." Ocean \& Coastal Management 102: 604-21. https://doi.org/10.1016/j.ocecoaman. 2014.11.001.

McCormack, G. 1996. The Emptiness of Japanese Affluence. London: Routledge.

Mittermeier, R. A., C. G. Mittermeier and P. Robes Gil. 1997. Megadiversity: Earth's Biologically Wealthiest Nations. 1st English edition. Mexico City: CEMEX.

Mo, W., M. Lee, M. Uchida, M. Inatomi, N. Saigusa, S. Mariko and H. Koizumi. 2005. "Seasonal and Annual Variations in Soil Respiration in a CoolTemperate Deciduous Broad-Leaved Forest in Japan." Agricultural and Forest Meteorology 134 (1-4): 81-94. https://doi.org/10.1016/j.agrformet. 2005.08.015.

MOEJ (Ministry of the Environment, Japan). n.d.[a]. Ramsar Sites in Japan, p. 2. Accessed 19 October, 2018. https://www.env.go.jp/en/nature/npr/ramsar_ wetland/pamph/ramsarpamphen/RamsarSites_en_web02.pdf.

MOEJ (Ministry of the Environment, Japan). n.d.[b]. Ramsar Sites in Japan, p. 3. Accessed 19 October, 2018. https://www.env.go.jp/en/nature/npr/ramsar_ wetland/pamph/ramsarpamphen/RamsarSites_en_web03.pdf.

MOEJ (Ministry of the Environment, Japan). n.d.[c]. Basic Policy for Nature Restoration. Accessed 19 October, 2018. https://www.env.go.jp/en/nature/ npr/bpnr.pdf. 
MOEJ (Ministry of the Environment, Japan). 2001. "Jūyō shicchi no sentei (torimatome kekka) ni tsuite (重要湿地の選定 (とりまとめ結果)について).” Media release. Ministry of the Environment, 27 December. Accessed 20 June, 2019. http:// www.env.go.jp/press/press.php?serial=3068.

MOEJ (Ministry of the Environment, Japan). 2009. Nature Restoration Projects in Japan: Towards Living in Harmony with the Natural Environment. Accessed 3 March, 2019. https://www.env.go.jp/en/nature/npr/nrp_japan/ pdf/full.pdf.

MOEJ (Ministry of the Environment, Japan). 2012. The National Biodiversity Strategy of Japan 2012-2020: Roadmap towards the Establishment of an Enriching Society in Harmony with Nature. 28 September. Accessed 19 October, 2018. https://www.env.go.jp/press/files/en/528.pdf.

Murray, N., R. Clemens, S. Phinn, H. Possingham and R. Fuller. 2014. "Tracking the Rapid Loss of Tidal Wetlands in the Yellow Sea." Frontiers in Ecology and the Environment 12 (5): 267-72. https://doi.org/10.1890/130260.

Nakamura, K., K. Tockner and K. Amano. 2006. "River and Wetland Restoration: Lessons from Japan.” BioScience 56 (5): 419-29. https://doi.org/10.1641/ 0006-3568(2006)056[0419:RAWRLF]2.0.CO;2.

Onodera, H., T. Watanabe and R. Kamezawa. 2007. "Idea of Nature Restoration." Global Environmental Research 11: 95-111.

Ramsar Convention Secretariat. 2014. "Ramsar Implementation in Japan." Ramsar, May 14. Accessed 19 October, 2018. https://www.ramsar.org/news/ramsarimplementation-in-japan.

Ramsar Network Japan. 2015. Increasing Japan's Ramsar Sites from 50 to 100. Accessed 20 June, 2019. http://www.ramnet-j.org/ramsar_cop12/wetland50100flyer.pdf.

Ramsar Sites Information Service. 2015. Ramsar Information Sheet: Japan, Higashiyoka-higata. 12 November. Accessed 19 October, 2018. https://rsis. ramsar.org/RISapp/files/RISrep/JP2234RIS_1505_en.pdf.

Sands, P. and J. Peel. 2018. Principles of International Environmental Law. Cambridge: Cambridge University Press.

Secretariat of the Convention on Biological Diversity. 2011. Contribution of Ecosystem Restoration to the Objectives of the CBD and a Healthy Planet for All People. Accessed 19 October, 2018. https://www.cbd.int/doc/publications/cbd-ts62-en.pdf.

SER (Society for Ecological Restoration). 2004. SER International Primer on Ecological Restoration. Accessed 31 May, 2019. https://c.ymcdn.com/sites/ www.ser.org/resource/resmgr/custompages/publications/SER_Primer/ser_ primer.pdf.

Shimba, T. 2007. A Photographic Guide to the Birds of Japan and North-East Asia. Yale University Press: New Haven and London. 
Singleton, J. 2015. “The Sneeze Trees: Ridding Japanese Forests of Pollen.” Nippon. com, 4 April. Accessed 3 March, 2019. https://www.nippon.com/en/ nipponblog/m00081/the-sneeze-trees-ridding-japanese-forests-of-pollen. html.

Takahashi, M. 2009. "Overview of the Structure and the Challenges of Japanese Wildlife Law and Policy." Biological Conservation 142 (9): 1958-64. https:// doi.org/10.1016/j.biocon.2009.05.009.

Takeuchi, K., K. Ichikawa and T. Elmqvist. 2015. "Satoyama Landscape as SocialEcological System: Historical Changes and Future Perspective." Current Opinion in Environmental Sustainability 19: 30-39. https://doi.org/10.1016/j. cosust.2015.11.001.

Telesetsky, A., A. Cliquet and A. Akhtar-Khavari. 2017. Ecological Restoration in International Environmental Law. London: Routledge. https://doi.org/ $10.4324 / 9781315757605$.

Totman, C. 1989. The Green Archipelago: Forestry in Preindustrial Japan. Los Angeles: University of California Press.

Totman, C. 2014. A History of Japan. New Jersey: Blackwell Publishing.

Tsujii T. and K. Sasagawa, eds. 2012. Thirty-three Examples of the Cultures and Technologies of Wetlands in Japan: Relationships with Local People and Communities. Tokyo: Wetlands International Japan. Accessed 19 October, 2018. http://archive.ramsar.org/pdf/33-Cultures-Technologies-booklet_ Japan.pdf.

Wada, T, T. Mitsushio, S. Inoue, H. Koike and R. Kawabe. 2016. "Movement Patterns and Residency of the Critically Endangered Horseshoe Crab (Tachypleus tridentatus) in a Semi-Enclosed Bay Determined Using Acoustic Telemetry." PLOS ONE 11 (2). https://doi.org/10.1371/journal.pone.0147429.

Watabe, Y. and S. Sassa. 2016. "History of Land Reclamation Using Dredged Soils at Tokyo Haneda Airport." Japanese Geotechnical Society Special Publication 2 (51): 1784-89. https://doi.org/10.3208/jgssp.TC217-04.

Zöckler, C., S. Delany and W. Hagemeijer. 2003. "Wader Populations are DecliningHow will we Elucidate the Reasons?” Wader Study Group Bull 100: 202-11. 